\title{
Examination of Sustainability Strategies of Enterprises that Operate in the Sports Industry
}

\section{Arif Yüce $^{1 *}$ (D) | Sevda Gökce Yüce ${ }^{1}$ | Hakan Katırcı'}

${ }^{1}$ Eskişehir Technical University, Department of Sports Management, Faculty of Sports Science, Eskişehir, Turkey

* Correspondence to: Arif Yüce, Eskişehir Technical University, Department of Sports Management, 2 Eylul Campus, Faculty of Sports Science, Eskişehir, Turkey.

E-mail: arifyuce@eskisehir.edu.tr

\begin{abstract}
The concept of sustainable production/consumption is one of the key points that need to be addressed in terms of measures and alternatives. As one of the most important industries today, the sports industry appeals to a wide range of consumers through various goods and services offered to consumers. The present view is that it is important to look out for sustainable production/consumption and to implement sustainability strategies both in terms of enterprises and of products and services offered to consumers. In this context, the main purpose of this study is to describe and examine the sustainability strategies of enterprises that produce goods and services in the sports sector. Within the scope of this inquiry, this study utilized the qualitative research technique of semi-structured interviewing. The interviews with senior managers in the sports sector were conducted in the Turkish city of Eskişehir. The results showed that the awareness levels of the companies regarding sustainability are lacking and that the corresponding strategies implemented were also insufficient.
\end{abstract}

Keywords: sports, sustainability, sustainability in sports, sustainable strategies in sports.

Article info: Received 22 February 2020 | revised 28 May 2020 | accepted 30 June 2020

Recommended citation: Yüce, A., Yüce, S. G., Katırcı, H. (2020). Examination of Sustainability Strategies of Enterprises that Operate in the Sports Industry. Indonesian Journal of Sustainability Accounting and Management, 4(1), 134-144. https://doi.org/10.28992/ijsam.v4i1.265.

\section{INTRODUCTION}

Although there are different definitions and approaches for the concept of sustainability from the past to the present, the most widely accepted definition has been put forward by the World Commission on Environment and Development in the report named "Our Common Future." In this report, the concept of sustainability is defined as "Meeting the needs of the present without compromising the ability of future generations to meet their own needs" (WCED Report, 1987). It can be argued that there are environmental, social, and economic elements at the core of the concept of sustainability, which refers to the balance needed between both short and long periods, and that all these elements are intertwined with each other, influenced by each other, and they are in an interaction (Appleton, 2006; Diesendorf, 2000; Fischer et al., 2008; WCED Report, 1987). Environmental sustainability means protecting nature and transferring it to the next generations without losing 
its essence, in other words protecting natural capital (Goodland, 1995; Goodland \& Daly, 1996; Lal, 2016). Social sustainability primarily refers to the equality between generations, whereas it aims to provide all the rights that the human, who is a source of labor, owns in both their daily lives and work lives at an optimal level (Choi \& Ng, 2011; Littig \& Griessler 2005). The concept of economic sustainability, however, refers to the self-sustainability of economic systems based on the concept of capital and the efficient use of labor, raw materials, and energy (Basiago, 1998; Choi \& Ng, 2011; Kaptein \& Wempe, 2001; Spangenberg, 2005).

Sports undertakes significant tasks in many aspects of social, environmental, and economic sustainability due to the different dynamics it embodies (Casper \& Pfahl, 2015; McCullough \& Kellison, 2018). In addition, it is stated that there is a strong link between sports and sustainable development, thus sports have both an impact on the concept of sustainability and is influenced by the concept of sustainability (IOC, 2006). The United Nations acknowledges sports as one of the leading forces of sustainable development in its published reports and cites it as a powerful tool within the "2030 Sustainable Development Goals" (United Nations, 2015; United Nations (UN), 2017). In parallel, in the "Sustainable Changes" conference held in 2018, it was emphasized that sports is one of the leading sectors within the concept of sustainability (Campelli, 2019).

The sports industry covers all tangible-intangible products with goods or services that are directly or indirectly related to sports (Funk et al., 2016). With a market share of about \$1.3 trillion (Plunket Research, 2018) and one of the most important industries today, the sports industry caters to a broad range of consumers through the wide variety of goods and services it offers to consumers (Yüce et al., 2017). At this point, the importance of ensuring that every product (goods and services) within the sports industry holds sustainability features. In addition, raising awareness about and having knowledge of the concept of sustainability and managing human resources accordingly in their management strategies are also among the important issues to meet their diversifying demands and needs on environmental issues in the scope of sports management (Casper \& Pfahl, 2012; Gholami et al., 2016). Along with the leading firms of the sports industry worldwide, many organizations have a variety of activities on sustainability. At this point, it is seen that companies producing international level sports products have adopted production policies based on sustainability factor especially since the 2000s, and have carried out communication campaigns accordingly (Adidas, 2019; Nike, 2019; Puma, 2019; United Armour, 2019). Nevertheless, although the firms producing sports goods and services have adopted the sustainability factor in their production and management strategies globally, there is no perceptible information on the extent to which these strategies are adopted and implemented on a local scale.

Because of the features that the sports and sports industry own, the sustainable productionconsumption approach in sports products is one of the key points to focus on within the scope of both precautions and alternatives (Trail \& McCullough, 2020). At this point, it is considered crucial that sustainable production-consumption is pursued and strategies related to sustainability are implemented for both enterprises and the products and services offered to consumers. In this context, the main objective of this research is to examine the strategies related to sustainability of the enterprises producing goods and services in the sports sector on a local scale and to reveal the existing situation.

\section{METHODS}

Within the scope of the research, semi-structured interview technique, which is one of the qualitative research techniques, was utilized. Semi-structured interviews, which are an interactive process based on questions and answers for a specific purpose, enable the acquisition of important information that cannot be obtained by quantitative research methods such as questionnaires or scales (Gupta \& Awasthy, 2015; Nathan et al., 2018; 
Adams, 2010). In this context, the semi-structured interview technique was preferred in order to obtain more qualified information in the study. The population of the research consists of enterprises operating in Eskişehir and producing goods and services in the sports industry, while the sample consists of total 14 firms, six of which produce sports goods and eight of which produce sports services. In order to determine the participants, the judgment sampling method which is widely used in qualitative researches, was utilized. Judgmental sampling refers to the sampling process in which researchers decide on the most accurate sample selection method by using their knowledge, experience, and judgment on the relevant subject (Hall \& Hall, 2008). In accordance with the objective of the research, the interviews were conducted between January 1 and March 10, 2019 with the senior managers of the firms producing goods and services in the sports sector in Eskişehir and the current situation was determined. In order to determine the views and strategies related to sustainability of the senior managers and the firms they are affiliated with, two different semi-structured interview forms created by the researchers were used. Accordingly, interview forms created within the framework of the relevant literature and expert opinions have been prepared in two different ways in order to be applied to the managers of the firms producing sports products. There were nine questions in the interview form for the managers of the firms producing sports services and six questions in the form for the managers of the firms producing sports goods. The relevant questions are shown in Tables 1 and 2.

Table 1 Interview Form Questions for Managers of Firms Providing Sports Service

1. Could you please share your knowledge about sustainability?

2. Do any sustainability features exist in the buildings of the facilities where you work? Please specify.

3. Are there informative/awareness-raising activities about sustainability for employees and managers in the facilities where you work? Or are there any related policies? Please specify.

4. Does the sports hall or brand you work with have policies or activities to inform/raise awareness of the users-customers about sustainability? Please specify.

5. Are there any products/equipment, systems, etc. carrying sustainable features in the facilities where you work? Please specify.

6. Is there any energy-saving equipment in the facilities where you work? Please specify.

7. Is energy-efficient lighting, etc. used in the facilities where you work? If yes, where are they used?

8. Are there recyclable waste collection bins in the facilities where you work?

9. Do you receive requests about products with sustainable features in the sports hall where you are managing?

Table 2 Interview Form Questions for the Managers of the Firms Producing Sports Goods

1. Could you please share your knowledge about sustainability?

2. Do the store or brand you work for have policies to inform/raise awareness of their employees and managers about sustainability? Please specify.

3. Do the store, brand, or brands you work for have policies or activities to inform/raise awareness of the users-customers about sustainability? Please specify.

4. Do the brand or brands you work with have product/products with sustainable features? If yes, which features do they have?

5. What are the pricing policies of the brand or brands you work with regarding product/products with sustainable features, if any? (More expensive/cheaper than their equivalents, etc.)

6. Do you receive requests for products with sustainable features in the store where you work? Do you receive information request about these products?

As indicated in Tables 1 and 2, the individuals working in the firms producing goods and services in the sports sector have been asked mainly about their management and strategies regarding the sustainability concept understanding of themselves and of their firms. The interviews were recorded with sound recording devices and then deciphered and converted into written texts. The interviews, which were converted into written texts, were analyzed and sampled by three researchers with a Ph.D. degree using the content analysis method with the help of NVivo 12 program. The main purpose of content analysis, which is frequently used in 
the social sciences, is to gather similar data within the framework of specific concepts and themes and to organize and interpret them in an understandable manner. The content analysis process consists of coding data, finding themes, editing codes and themes, and defining and interpreting findings (Neuendorf, 2002; Taylor et al., 2016). During content analysis, Miles and Huberman (1994) formula is taken as the basis for calculating the reliability coefficient between coders. In content analysis, the reliability coefficient between coders is expected to be 0.80 and above. It was determined that the reliability coefficients for the codes and themes determined within the scope of the research ranged from 0.80 to 1.00 (Tables 3 and 4). Accordingly, within the scope of the research, it can be stated that the reliability values between coders are at an acceptable level.

Table 3 Themes for the Understanding of Sustainability in Enterprises that Produce Services in Sports

\begin{tabular}{llc}
\hline \multicolumn{1}{c}{ Theme } & \multicolumn{1}{c}{ Codes } & Inter-Coder Reliability \\
\hline Facility/building sustainability & N/A & 1.00 \\
Energy-saving lighting & Awareness & 1.00 \\
Sustainability knowledge & Available & 1.00 \\
& No continuity information & 1.00 \\
Demand for products with sustainability features & Positive behavior & 1.00 \\
Sustainable equipment-system & N/A & 1.00 \\
& Water-saving equipment \\
Informing user-customer & Heat recovery & 1.00 \\
& Elliptical devices & \\
Energy saving & N/A & Banners \\
Informing employees & Elliptical \\
& Lighting & 1.00 \\
Waste collection-recycling & Energy-saving \\
& Individual information \\
\end{tabular}

Table 4 Themes for the Understanding of Sustainability in Enterprises that Produce Goods in Sports

\begin{tabular}{lcc}
\hline \multicolumn{1}{c}{ Theme } & Codes & Inter-coder Reliability \\
\hline Sustainability knowledge & Long term & Lifespan of earth \\
& Continuity & Balance \\
& No knowledge & \\
& N/A & 1.00 \\
Products with sustainability features & Project \\
& No knowledge \\
& Waste recycling & 1.00 \\
Demand for products with sustainability features & Advertisement effect \\
& Unknown \\
Store-brand policy & N/A \\
Pricing & Training \\
& Consciousness-raising \\
\hline
\end{tabular}




\section{RESULTS AND DISCUSSION}

The data obtained within the scope of the research were analyzed based on two understandings of sustainability of the enterprises that produce services in sports and the enterprises that produce goods in sports. Accordingly, the themes and codes that come out as a result of the related analyses are shown in Table 3-Figure 1 and Table 4-Figure 2, respectively.

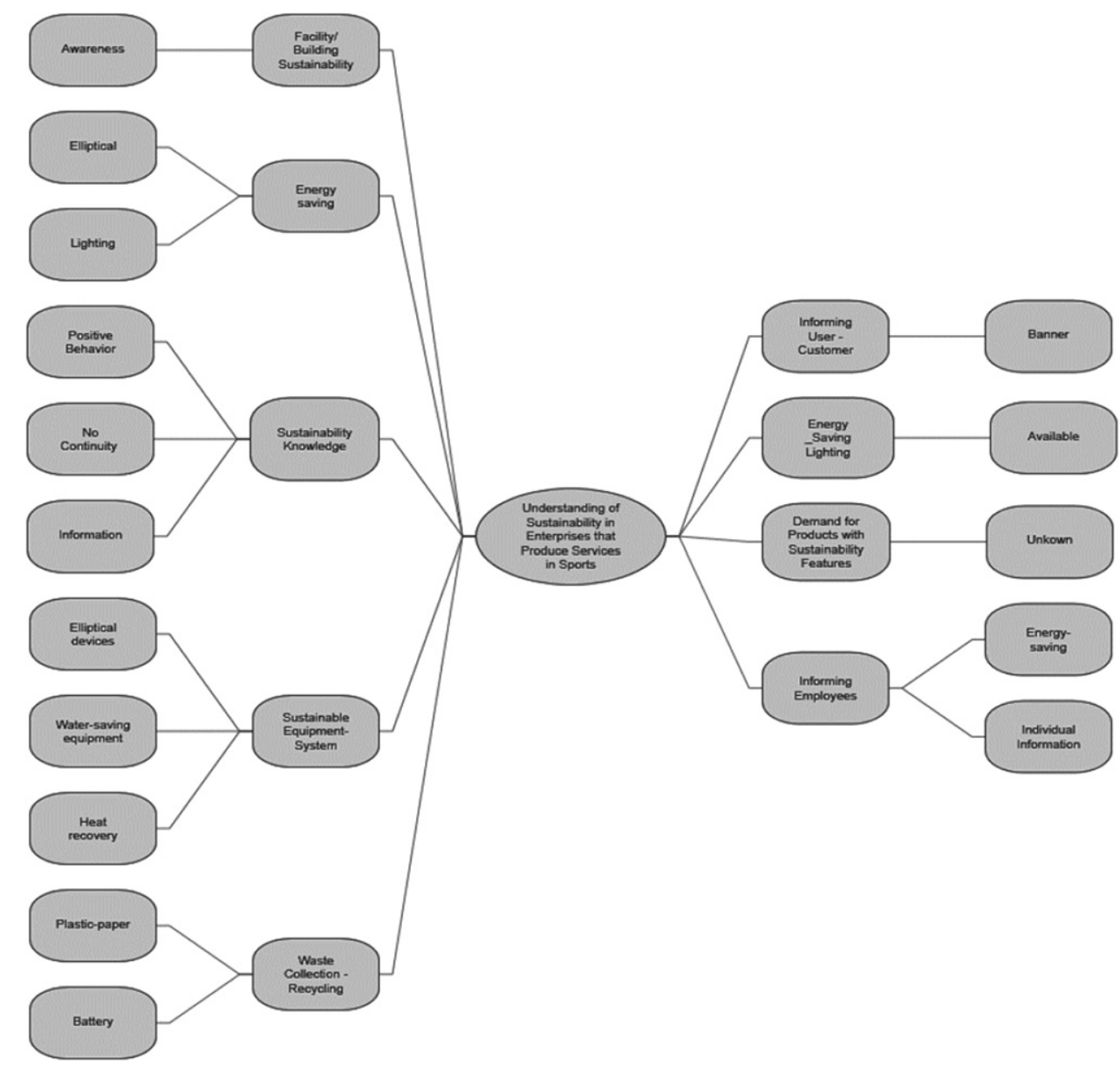

Figure 1 Themes of Sustainability in Enterprises that Produce Services in Sports

As can be seen in Table 3, nine different themes, namely "Facility/Building Sustainability," "Energy-Saving Lighting," "Sustainability Knowledge," "Demand for Sustainability Feature," "Sustainable Equipment-System, Informing Users-Customers," “Energy Saving," "Informing Employees," and "Waste Collection-Recycling," have been created to address the questions asked regarding the sustainability understanding in the enterprises that produce services in sports. There are 21 codes within the relevant themes. The reliability coefficient between the coders was determined as $(\alpha=1.00)$ in all themes.

As can be seen in Table 3, five different themes, namely Sustainability Knowledge, Product with Sustainable Feature, Demand for Product with Sustainable Feature, Store-Brand Policy, and Pricing, have been created in order to address the questions regarding the sustainability understanding in the enterprises that produce goods in sports. There are 16 codes within the relevant themes. It has been determined that the reliability coefficient between coders varies as $\alpha=0.80-1.00$. 


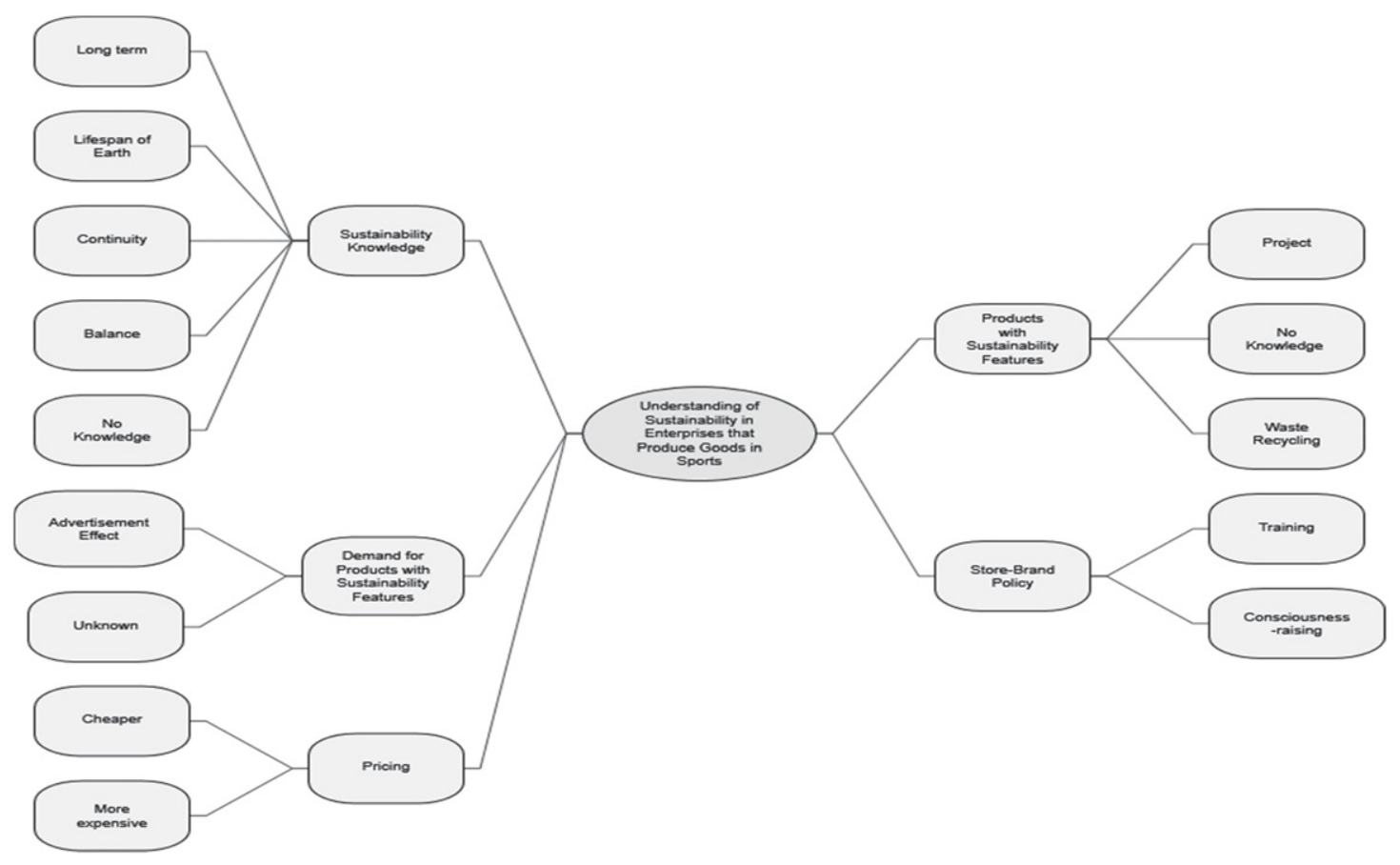

Figure 2 Themes of Sustainability in Enterprises that Produce Goods in Sports

In the scope of the study, the main aim of which is to examine the strategies related to sustainability in the activities of the enterprises producing goods and services in the sports sector on a local scale and to reveal the existing situation in this regard, it was determined that the enterprises producing both services and goods and the individuals managing these enterprises have no information and awareness at a sufficient level. Within the scope of the data obtained, it was determined that the individuals working in the enterprises producing services have no knowledge about sustainability or that those who have knowledge did not know the concept at a sufficient level. Accordingly, the individuals often interpreted the concept of sustainability as continuity and matched it with the continuity, profitability, etc. elements of the organization where they work. Also, some of the participants described the services that they provide friendly and genially to the consumers as a factor of sustainability. Although this can be considered within the scope of social sustainability, the concept of sustainability is not just a concept focused on continuity and human relations, but rather an issue that requires economic, social, and environmental integrity and concerns the future of all humanity with high-level importance (Herremans \& Reid, 2002; Thompson, 2010).

All of the individuals who participated in the study, which was carried out in particular for sports and health centers (Lee, 2017), which is one of the most basic enterprise types that produce services in sports, stated that the buildings of the sports hall where they work do not carry sustainability features (LEED certificate, green building, etc.), whereas they also stated that energy-saving lighting is used in sports halls. The presence and use of solar panels, rainwater collection, and energy-efficient devices are among the key features that enhance the sustainability in sports and recreation facilities. All these systems and their use not only benefit the environment, but also have the potential to be economically beneficial if used correctly (Mitchell et al., 2016; Stinnett, 2013; Stinnett and Gibson, 2016). It can be stated that the number of sports facilities with sustainability features in Turkey is quite limited. At this point, the fact that some of the sports halls do not have such feature because of their small scale can be considered as normal. Despite this fact, the use of 
energy-saving lighting is a fairly common practice today (Goodlight, 2018). Therefore, the use of this kind of lighting can be considered as a necessity. The managers, who stated that there are products with sustainability feature among the equipment used in the sports hall and changing rooms, referred these mainly under the heading of elliptical devices while naming other features as water-saving batteries and heat recovery devices. Danko et al. (2012) emphasized the importance of green technologies that use kinetic energy instead of electrical energy to minimize energy use in sports halls and stated that the elliptical machines used would not only help individuals develop their own bodies, but also contribute to the development of the world. In parallel, it is thought that the individual who is psychologically satisfied will contribute to social sustainability as well. Today, water-saving mixer batteries are considered very important to control water usage and ensure the necessary savings (Englart \& Jedlikowski, 2019). Therefore, water-saving comes into the fore again as an important element in the enterprises such as sports-health halls where water is consumed heavily for the purpose of different services (Cohen et al., 2009; Porteshawver, 2009). The managers have stated that there are waste collection bins for recycling plastic, paper, and batteries in the sports halls where they work. Eskişehir Tepebaşı Municipality carries out rigorous studies and services on the separation and collection of packaging waste (plastic, glass, paper, cardboard, metal, composite, etc.), vegetable oil wastes, battery wastes, textile wastes, and electrical and electronic good wastes from domestic wastes (Tepebaşı Municipality, 2019). Waste collection bins, which are encouraged with the support of the local government, are available in almost every building, especially, in neighborhoods, schools, and workplaces in Eskişehir. At this point, it can be stated that what is important is to keep up with and support the correct functioning of the system that is encouraged. Sports-health centers are among the areas where it is needed to be sensitive about drinking water as well. Drinking waters used in these centers are offered to consumers usually in plastic bottles. Keeping these plastic bottles, which are offered to consumers for one time use, among recyclable waste and making the necessary evaluations will contribute ecologically to sustainability in a social way both on the basis of the company itself and the local authorities.

Although the managers stated that there was no demand from consumers for products or services with sustainability features, they added that they used posters and warnings to inform consumers and employees, and in the case of absence of these elements, they made efforts to inform them individually. However, it has been determined that the sports halls without any activities related to giving information/raising awareness are higher in number.

The codes such as continuity, balance, long term, and lifespan of the earth have come to the fore within the scope of the knowledge regarding the concept of sustainability of the individuals who are managers in the enterprises that produce goods in sports. Casper and Pfahl (2012) noted that increasing awareness and knowledge regarding the concept of sustainability of sports managers are important factors in order to meet the demands and needs that differ along with changing conditions. At this point, it is considered important and valuable that the individuals who are senior managers at the local level are aware of all these elements included in the concept of sustainability both in terms of managerial policies and local strategies, which will be created in the future (King \& Church, 2017).

The studies have shown that sustainability-conscious producers have positive impacts on raising sensitivity and awareness of the community for the concept of sustainability in that vein (Chard et al., 2013; Goworek et al., 2012; Schmidt, 2006; Trendafilova et al, 2013). Within the scope of the study, it was stated that only one of the firms producing sports goods does not have products with sustainability features. Today, many firms that produce sports goods put emphasis on the products that have sustainability features. Coming out as a kind of social sensitivity, it also takes its place among the activities used in social responsibility and public relations campaigns and preferred to increase the sensitivity and awareness of users (Adidas, 2019; Nike, 2019; Puma, 
2019; United Armour, 2019). Again, as a result of the campaigns to raise awareness and consciousness, the managers stated that consumers demand the products that they see in advertisements or the products that have sustainability features. This shows that the activities carried out have partially reached their target. Similarly, Reinders (2019) states that the fact that textile brands producing sports products design labels related to sustainability and adopt an understanding of sustainability will contribute to the adoption of sustainability by consumers as well. It has been stated that the products with sustainability features of the firms are produced using recyclable materials and from sustainability-oriented projects. It has been determined that the firms with sustainability awareness carry out up-to-date trainings and hold meetings to raise awareness of their employees on this subject, but this is limited to only three firms. Finally, it is determined that there is no consistency in the pricing of products with sustainability features and that some firms offer sustainable products to their consumers with more affordable pricing policy than their equivalents due to the low cost of recyclable raw materials, whereas, on the contrary, some other firms offer these products with a more expensive pricing strategy. The studies on sustainability-conscious consumers concluded that the products with sustainability features would be preferred even if they were more expensive (Kotler, 2011). Accordingly, it is possible to comment that the pricing policies and firm strategies that are likely to take place after the awareness-raising process are the results of the socio-economic studies that are carried out for the consumers in the target audience.

\section{CONCLUSION}

Within the framework of all this information, it is determined that the level of awareness of the firms for sustainability is not sufficient and that the strategies applied in this direction are also insufficient. In addition, it has been determined that the knowledge of the individuals managing the enterprises that produce goods in sports and their management and strategies for sustainability, in general, are more comprehensive and effective than the managers in the enterprises that produce services. Both the low level of knowledge and awareness of the individuals, who are in the position of senior managers in service-producing enterprises, as well as the lack of similar strategy policies in the firms where they are employed, create negative situations for the future. At this point, it is first necessary to inform and raise awareness of these individuals and enterprises. Likewise, waste management and the use of energy-efficient devices are important elements in these sports halls. Following the implementation of the related practices, the practice of determining strategies for generating their own energy is also seen as a practice with significant potential for sports halls. It is stated that the elliptical devices and some standard exercise equipment highlighted in the study work with kinetic energy. Today, equipment for converting this kinetic energy into electrical energy is designed and implemented (Meinhold, 2010). Ghasemi et al. (2020) stated that operational, communicational, organizational, and supplementary exercises have a significant effect on the sustainability of sports businesses. In this context, the provision and adoption of the products and services that have sustainability features in both design and activities of sports halls and in the services offered to consumers will contribute to the future of firms and the world in the long term, in social, economic, and environmental dimensions.

\section{ORCID}

Arif Yüce (i) http://orcid.org/0000-0003-3756-3870 


\section{REFERENCES}

Adams, W. C. (2010). Conducting semi-structured interviews. In: Wholey, J. S., Hatry, H. P., \& Newcomer, K. E. (Eds.), Handbook of Practical Program Evaluation. San Francisco, CA: Josey-Bass (pp. 365-377).

Adidas (2019). Sustainability history. https://www.adidas-group.com/en/sustainability/managing-sustainability/ sustainability-history/

Appleton, A. F. (2006). Sustainability: A practitioner's reflection. Technology in Society, 28(1-2), 3-18. https://doi.org/10.1016/j.techsoc.2005.10.001

Basiago, A. D. (1998). Economic, social, and environmental sustainability in development theory and urban planning practice. Environmentalist, 19(2), 145-161. https://doi.org/10.1023/A:1006697118620

Campelli, M. (2019). Sport can become the leading industry in sustainability—If it changes its approach, says IOC. https://sportsustainabilityjournal.com/analysis/sport-can-become-the-leading-industry-in-sustainability-ifit-changes-its-approach-says-ioc/

Casper, J. M., \& Pfahl, M. E. (2012). Environmental behavior frameworks of sport and recreation undergraduate students. Sport Management Education Journal, 6(1), 8-20. https://doi.org/10.1123/smej.6.1.8

Casper, J. M., \& Pfahl, M. E. (Eds.). (2015). Sport management and the natural environment: Theory and practice. Routledge.

Chard, C., Mallen, C., \& Bradish, C. (2013). Marketing and environmental sustainability in the sport sector: Developing a research agenda for action. Journal of Management and Sustainability, 3(1), 45. http://dx.doi. org/10.5539/jms.v3nlp45

Choi, S., \& Ng, A. (2011). Environmental and economic dimensions of sustainability and price effects on consumer responses. Journal of Business Ethics, 104(2), 269-282. https://doi.org/10.1007/s10551-011-0908-8

Cohen, R., Ortez, K., \& Pinkstaff, C. (2009). Increasing water efficiency in California's commercial, industrial, and institutional (CII) sector. 1-40.

Danko, P.J., Hanley, J. R., \& Williams, L. (2012). Get fit, save energy; powering the rec through energy-generating Equipment. Stander Symposium Projects. 181. https://ecommons.udayton.edu/stander_posters/181

Diesendorf, M. (2000). Sustainability and sustainable development. In Dunphy, D., Benveniste, J., Griffiths, A., \& Sutton, P. (Eds.), Sustainability: The corporate challenge of the 21st century, Sydney: Allen \& Unwin, chap. 2, (pp. 19-37).

Englart, S., \& Jedlikowski, A. (2019). The influence of different water efficiency ratings of taps and mixers on energy and water consumption in buildings. SN Applied Sciences, 1(6), 525. https://doi.org/10.1007/ S42452-019-0539-8

Fischer, K., Steimle, U., \& Zink, K. (2008). Human factors, business excellence and corporate sustainability: Differing perspectives, joint perspectives. In K. Zink (Ed.), Corporate sustainability as a challenge for comprehensive management. Physica Publishing, (pp. 3-18).

Funk, D., Alexandris, K., \& McDonald, H. (2016). Sport consumer behaviour: Marketing strategies. Routledge.

Ghasemi, M. R., Khoshnam, E., Far, A. T., \& Mohammadzadeh, Y. (2020). Investigating the role of environmental management exercises on the sustainability of sports businesses. Sistemas \& Gestão, 15(1), 53-58. https:// doi.org/10.20985/1980-5160.2020.v15n1.1618

Gholami, H., Rezaei, G., Saman, M. Z. M., Sharif, S., \& Zakuan, N. (2016). State-of-the-art green HRM System: Sustainability in the sports center in Malaysia using a multi-methods approach and opportunities for future research. Journal of Cleaner Production, 124, 142-163. https://doi.org/10.1016/j.jclepro.2016.02.105

Gupta, R. K. \& Awasthy, R. (2015). Qualitative research in management methods and experiments. Sage Publications.

Goodland, R. (1995). The concept of environmental sustainability. Annual Review of Ecology and Systematics, 26(1), 1-24, https://doi.org/10.1146/annurev.es.26.110195.000245.

Goodland, R., \& Daly, H. (1996). Environmental sustainability: Universal and non-negotiable. Ecological Applications, 6(4), 1002-1017. https://doi.org/10.2307/2269583 
Goodlight (2018). Gym owners make substantial energy savings with LED lighting. https:/www.goodlight.co. uk/blog/gym-owners-make-substantial-energy-savings-with-led-lighting/

Goworek, H., Fisher, T., Cooper, T., Woodward, S., \& Hiller, A. (2012). The sustainable clothing market: An evaluation of potential strategies for UK retailers. International Journal of Retail \& Distribution Management, 40(12), 935-955. https://doi.org/10.1108/09590551211274937

Hall, N. A., \& Hall, R. (2008). Applied social research. Macmillan Education AU.

Herremans, I. M., \& Reid, R. E. (2002). Developing awareness of the sustainability concept. The Journal of Environmental Education, 34(1), 16-20. https://doi.org/10.1080/00958960209603477

International Olympic Committee. (2006). IOC guide on sport, environment and sustainable development. International Olympic Committee.

Kaptein, M., \& Wempe, J. (2001). Sustainability management: Balancing conflicting economic, environmental and social corporate responsibilities. Journal of Corporate Citizenship, 1(2), 91-106. https://www.jstor.org/ stable/10.2307/jcorpciti.2.91

King, K., \& Church, A. (2017). Lifestyle sports delivery and sustainability: Clubs, communities and user-managers. International Journal of Sport Policy and Politics, 9(1), 107-119. https://oi.org/10.1080/19406940.2017. 1289236

Kotler, P. (2011). Reinventing marketing to manage the environmental imperative. Journal of Marketing, 75(4), 132-135. https://doi.org/10.1509\%2Fjmkg.75.4.132

Lal, R. (2016). Environmental sustainability. In: Lal, R., Kraybill, D., Hansen, D., Singh, B., Mosogoya, T., \& Eik, L. (eds) Climate change and multi-dimensional sustainability in African agriculture (pp. 3-11). Cham: Springer. https://doi.org/10.1007/978-3-319-41238-2_1.

Lee, S. Y. (2017). Service quality of sports centers and customer loyalty. Asia Pacific Journal of Marketing and Logistics, 29(4), 870-879. https://doi.org/10.1108/APJML-10-2016-0191

Littig, B. \& Griessler, E. (2005). Social sustainability: A catchword between political pragmatism and social theory. International Journal for Sustainable Development, 8(1/2), 65-79. https://doi.org/10.1504/IJSD.2005. 007375

McCullough, B. P., \& Kellison, T. B. (2018). Routledge handbook of sport and the environment. Routledge.

Meinhold, B. (2010). ReRev makes energy generating gyms a reality. https://inhabitat.com/revrev-makesenergy-generating-gyms-a-reality/

Miles, M. B. \& Huberman, A. M. (1994). Qualitative Data Analysis: An Expanded Sourcebook. (2nd Ed). Thousand Oaks, CA: Sage.

Mitchell, A., Petrilli, M., Sundaram, D., Pisani-Gareau, T., \& Seminar, E. S. S. (2016). Building a green recreation complex: Sustainable considerations for the future of Boston College Campus Recreation.

Nathan, S., Newman, C. \& Lancaster, K. (2018). Qualitative interviewing. In P., Liamputtong (Ed.), Handbook of research methods in health social sciences (pp. 1-20). Springer Singapore.

Neuendorf, K. (2002). The content analysis guidebook. Sage Publications.

Nike (2019). SASB summary. https://purpose.nike.com/reports

Plunket Research (2018). Sports \& recreation industry statistics and market size overview. https://www. plunkettresearch.com/statistics/Industry-Statistics-Sports-Industry-Statistic-and-Market-Size-Overview/

Porteshawver, A. B. (2009). Green sports facilities: Why adopting new green-building policies will improve the environment and community. The Marquette Sports Law Review, 20(1), 241.

Puma (2019). Business and sustainability report 2017. https://about.puma.com/en/sustainability/reporting

Reinders, S. (2019). The adoption of Sustainability Labels for Brands in the Sports and Outdoor Textile Industry A case study on the bluesign ${ }^{\circledR}$ approved product label. Utrecht University, Faculty of Geosciences Theses, [Master's thesis].

Schmidt, C. W. (2006). Putting the earth in play: Environmental awareness and sports. Environmental Health Perspectives, 114(5), 286-294. https://doi.org/10.1289/ehp.114-a286

Spangenberg, J. H. (2005). Economic sustainability of the economy: Concepts and indicators. International Journal of Sustainable Development 8(1-2), 47-64. https://doi.org/10.1504/IJSD.2005.007374 
Stinnett, T. B. (2013). Sustainability and collegiate recreational sports facilities. Paper 1386. ThinkIR: The University of Louisville's Institutional Repository.

Stinnett, B., \& Gibson, F. (2016). Sustainable facility development: perceived benefits and challenges. International Journal of Sustainability in Higher Education, 17(5), 601-612. https://doi.org/10.1108/IJSHE09-2014-0133.

Taylor, S. J., Bogdan, R., \& Devault, M. L. (2016). Introduction to qualitative research methods a guidebook and resource. John Wiley \& Sons.

Tepebaşı Municipality (2019). Waste Management. http://www.tepebasi.bel.tr/calismadetay.asp?hid=4937

Thompson, P. B. (2010). What sustainability is (and what it isn't). Pragmatic sustainability. Theoretical and practical tools. Routledge.

Trail, G. T., \& McCullough, B. P. (2020). Marketing sustainability through sport: Testing the sport sustainability campaign evaluation model. European Sport Management Quarterly, 20(2), 109-129. https://oi.org/ 10.1080/16184742.2019.1580301

Trendafilova, S., Babiak, K., \& Heinze, K. (2013). Corporate social responsibility and environmental sustainability: Why professional sport is greening the playing field. Sport Management Review, 16(3), 298-313. https://doi. org/10.1016/j.smr.2012.12.006

Under Armour (2019). Sustainability at Under Armour. https://about.underarmour.com/community/sustainability

United Nations (2015). Transforming our world: The 2030 agenda for sustainable development. UN.

United Nation (UN) (2017). 2030 Agenda acknowledges sport as key enabler of sustainable development, peace, deputy secretary-general says during high-level exhibition. United Nation Press.

WCED Report (1987). World commission on environment and development, 1987. Our common future. Brundtland report. Oxford University Press.

Yüce, A., Katırcı, H., \& Gökce, S. (2017). From traditional to digital sports marketing: A conceptual study. Journal of Academic Social Science Studies, Spring II (55), 543-556. http://dx.doi.org/10.9761/JASSS6947 